\title{
Peran Otoritas Jasa Keuangan dalam Pengawasan Lembaga Baitul Maal wa Tamwil (BMT): Studi Kasus BMT Global Insani
}

\author{
Tita Novitasari \\ Fakultas Syariah dan Hukum UIN Syarif Hidayatullah \\ novitasaritita@gmail.com
}

\begin{abstract}
This article discusses the role and involvement of the Financial Services Authority (OJK) in overseeing the Baitul Maal wa Tamwil (BMT) institution, especially in relation to the protection of illegal BMT customers. After the legislation and enactment of Law Number 1 of 2013 about Microfinance Institutions (UULKM), the establishment, guidance, regulation, and supervision of BMTs have changed. BMT organizations that originally could have been in the form of cooperative, foundation, limited liability companie, and even non-governmental organization, now must be in the form of cooperative or limited liability companie. However, in terms of guidance, OJK still needs to coordinate with ministries that carry out cooperative and domestic affairs, and therefore LKM guidance are actually under three authorities: OJK, the Ministry of Cooperatives and SMEs, and the Ministry of Home Affairs. Whereas in terms of regulation and supervision, authority is absolutely in OJK. The validity of UULKM also requires BMT to obtain a business license from OJK, and if not, the status means illegal. Taking the BMT (illegal) Global Insani case as an example, this article shows the role of OJK in BMT supervision has been expanded, from the institutional to the consumer protection aspects. Consumer protection efforts that can be done by OJK are through the mechanism of complaint, investigation, reporting, and prosecution.
\end{abstract}

Keywords: baitul maal wa tamwil; legal basis; illegal; customer protection. 


\section{Abstrak}

Artikel ini membahas peran dan keterlibatan Otoritas Jasa Keuangan (OJK) dalam mengawasi lembaga Baitul Maal wa Tamwil (BMT), terutama dikaitkan dengan perlindungan nasabah BMT ilegal. Pasca dibentuk dan diberlakukannya Undang-undang Nomor 1 Tahun 2013 tentang Lembaga Keuangan Mikro (UULKM), maka pendirian, pembinaan, pengaturan, dan pengawasan BMT menjadi berubah. Organisasi BMT yang semula dapat berupa koperasi, yayasan, perseroan terbatas, dan bahkan kelompokswadaya masyarakat, saat ini harus berbentuk koperasi atau perseroan terbatas. Namun demikian, dalam hal pembinaan, OJK masih perlu berkoordinasi dengan kementerian yang menyelenggerakan urusan koperasi dan dalam negeri, dan karenanya LKM sesungguhnya berada di bawah tiga otoritas, yaitu OJK, Kementerian Koperasi dan UKM, dan Kementerian Dalam Negeri. Sedangkan dalam hal pengaturan dan pengawasan, kewenangan secara absolut ada pada OJK yang. Keberlakuan UULKM juga mewajibkan BMT memperoleh izin usaha dari OJK, dan jika tidak, statusnya berarti ilegal. Dalam artikel ini ditunjukkan, dengan mengambil contoh BMT (ilegal) Global Insani, peran OJK dalam pengawasan BMT telah diperluas, dari aspek kelembagaan hingga aspek perlindungan konsumen. Perlindungan konsumen yang dapat dilakukan OJK ialah melalui mekanisme pengaduan, penyelidikan, hingga pelaporan dan penuntutan.

Kata Kunci: baitul maal wa tamwil; landasan hukum; ilegal; perlindungan nasabah.

\section{A. Pendahuluan}

Artikel ini membahas peran dan keterlibatan Otoritas Jasa Keuangan (OJK) dalam mengawasi lembaga Baitul Maal wa Tamwil (BMT), terutama dikaitkan dengan perlindungan nasabah BMT ilegal. Pembahasan demikian dipandang perlu karena status badan usaha BMT beserta pihak atau lembaga yang mengawasinya mengalami perubahan pasca terbitnya Undang-Undang Nomor 1 Tahun 2013 tentang Lembaga Keuangan Mikro (UULKM). BMT yang sudah ada dan tidak menyesuaikan diri dengan perubahan ini akan dikategorikan sebagai ilegal. Dalam artikel ini, BMT Global Insani akan dijadikan contoh kasus dalam melihat bagaimana peran OJK terhadap BMT 
ilegal.

BMT sendiri merupakan Lembaga Keuangan Mikro (LKM) Syariah yang beroperasi berdasarkan prinsip-prinsip syariah. Pada awalnya BMT didirikan dan dikembangkan dengan menyesuaikan kondisi hukum dan kebutuhan pasar. Secara kelembagaan, badan hukum BMT dapat berbentuk koperasi, yayasan, perseroan terbatas (PT), dan bahkan kelompok swadaya masyarakat (KSM). Status hukum yang berbeda-beda ini menyebabkan BMT tunduk pada berbagai peraturan perundang-undangan yang berbeda-beda sesuai dengan kelembagaan yang dipilih. BMT berbentuk koperasi tunduk pada peraturan terkait koperasi; BMT berbentuk yayasan tunduk pada peraturan terkait yayasan; BMT berbentuk PT tunduk pada peraturan terkait PT; BMT berbentuk KSM tunduk pada UU Organisasi Masyarakat. Belakangan, dengan berlakunya UULKM, BMT berbentuk KSM tidak dimungkinkan lagi, karena badan hukum LKM harus berbentuk koperasi atau PT. ${ }^{1}$

Keberbedaan status hukum kelembagaan tersebut menimbulkan permasalahan tersendiri terkait dengan izin dan pengawasannya. Izin dan pengawasan BMT yang bebentuk koperasi ada di bawah Kementerian Koperasi dan Usaha Kecil Menengah (UKM); sedangkan BMT dengan bentuk PT berada di bawah kewenangan OJK. Namun demikian, karena UULKM mengatur "pembinaan, pengaturan, dan pengawasan LKM dilakukan oleh Otoritas Jasa Keuangan”, ${ }^{2}$ maka OJK berwenang penuh dalam pengaturan dan pengawasan BMT, sementara kewenangan Kementerian Koperasi dan UKM menjadi tereduksi.

Turut berwenangnya OJK dalam membina, mengatur, dan mengawasi BMT disebabkan BMT merupakan bagian dari LKM. Dalam UULKM disebutkan, LKM adalah "lembaga keuangan yang khusus didirikan untuk memberikan jasa pengembangan usaha dan pemberdayaan masyarakat, baik melalui pinjaman atau pembiayaan dalamusaha skala mikro kepada anggota dan masyarakat, pengelolaan simpanan, maupun pemberian jasa konsultasi pengembangan usaha

1 Pasal 5 ayat (1) UULKM.

2 Pasal 28 ayat (1) UULKM. 
yang tidak semata-mata mencari keuntungan". ${ }^{3}$ UULKM juga menegaskan, BMT dan lembaga lainnya yang dipersamakan harus tunduk pada UULKM setelah satu tahun UU berlaku. ${ }^{4}$ BMT dan lembaga lain yang dipersamakan, diwajibkan memeroleh izin usaha dari OJK paling lama satu tahun sejak UU berlaku. ${ }^{5}$

Keharusan BMT untuk segera menyesuaikan diri dengan UULKM tersebut ternyata belum banyak dilakukan. Data OJK menunjukkan, sebanyak 19.334 LKM dari total 637.838 LKM di Indonesia belum berstatus badan hukum. ${ }^{6}$

Dengan adanya peraturan wajib izin bagi BMT yang ingin beroperasi sebagai LKMS, maka tentu akan dikenal istilah BMT ilegal atau BMT tanpa izin. OJK mengatur, jika sampai 2016 belum terdaftar dan lapor OJK, BMT tersebut dianggap gelap atau ilegal. Artinya penyaluran dana kredit kepada nasabah dan segala aktivitas BMT termasuk ilegal. Data tahun 2015 menunjukkan, sekitar 50.00060.000 LKM ada di Jawa Tengah, dan sekitar 11.500 di antaranya tidak memiliki status badan hukum. ${ }^{7}$ Contoh BMT ilegal adalah BMT

3 Pasal 1 angka 1 UULKM.

4 Pasal 39 ayat (1) UULKM: "Pada saat Undang-Undang ini mulai berlaku, Bank Desa, Lumbung Desa, Bank Pasar, Bank Pegawai, Badan Kredit Desa (BKD), Badan Kredit Kecamatan (BKK), Kredit Usaha Rakyat Kecil (KURK), Lembaga Perkreditan Kecamatan (LPK), Bank Karya Produksi Desa (BKPD), Badan Usaha Kredit Pedesaan (BUKP), Baitul Maal wa Tamwil (BMT), Baitul Tamwil Muhammadiyah (BTM), dan/atau lembaga-lembaga lainnya yang dipersamakan dengan itu tetap dapat beroperasi sampai dengan 1 (satu) tahun terhitung sejak Undang-Undang ini berlaku”.

5 Pasal 39 ayat (2) UULKM: "Lembaga-lembaga sebagaimana dimaksud pada ayat (1) wajib memperoleh izin usaha dari Otoritas Jasa Keuangan paling lama 1 (satu) tahun terhitung sejak Undang-Undang ini berlaku”. Pasal 39 ayat (3) UULKM mengecualikan ketertundukan dengan UULKM pada Lembaga Perkreditan Desa dan Lumbung Pitih Nagari serta lembaga sejenisnya yang telah ada sebelum UULKM berlaku, "Lembaga Perkreditan Desa dan Lumbung Pitih Nagari serta lembaga sejenis yang telah ada sebelum UndangUndang ini berlaku, dinyatakan diakui keberadaaannya berdasarkan hukum adat dan tidak tunduk pada Undang-Undang ini”.

6 Sukma Ari Sanjaya, "Implementasi Undang-undang Nomor 1 Tahun 2013 tentang Lembaga Keuangan Mikro Terhadap Pembinaan dan Pengawasan Baitul Maal wat Tamwil oleh Otoritas Jasa Keuangan”, Skripsi, Fakultas Hukum Universitas Lampung, 2019, hlm. 40.

7 https: / finansial.bisnis.com/ read/20150121/90/393529/lkm-belum- 
Global Insani yang hingga tahun 2018 tidak memperoleh izin usaha baik sebagai koperasi maupun perseroan terbatas. ${ }^{8}$ Dengan statusnya yang ilegal, dan apalagi jika terbukti telah merugikan banyak nasabah, sebagaimana yang terjadi pada nasabah BMT Global Insani, ${ }^{9}$ maka menjadi pertanyaan, bagaimana peran OJK. Artikel ini akan membahas tentang landasan hukum dan status badan hukum BMT dan bagaimana pengaturan OJK terhadap BMT ilegal, khususnya terkait perlindungan nasabah BMT ilegal tersebut.

\section{B. Baitul Mal wa Tamwil: Pengertian, Landasan Hukum, dan Status Hukumnya}

Istilah baitul maal wal tamwil berasal dari kata baitul maal dan baitul tamwil. Baitul maal sendiri berasal dari kata bait yang berarti bangunan atau rumah dan maal yang berarti harta benda atau kekayaan; sehingga baitul maal dapat diartikan sebagai perbendaharaan (umum atau negara). Berdasarkan istilah, baitul maal adalah suatu lembaga atau badan yang bertugas untuk mengurusi kekayaan negara terutama keuangan, baik yang berkenaan dengan soal pemasukan dan pengelolaan maupun yang berhubungan dengan masalah pengeluaran dan lain-lain. ${ }^{10}$ Sedangkan istilah baitul tamwil berasal dari bait yang berarti rumah dan tamwil yang berarti pengembangan harta; sehingga baitul tamwil adalah suatu lembaga yang melakukan kegiatan pengembangan usaha-usaha produktif dan investasi dalam meningkatkan kesejahteraan pengusaha mikro melalui kegiatan pembiayaan dan menabung atau berinvestasi. ${ }^{11}$

Baitul maal wat tamwil (BMT) dengan demikian merupakan

berbadan-hukum-dianggap-ilegal-, "LKM Belum Berbadan Hukum Dianggap Ilegal”, 21/1/2015, diakses 18/5/2019.

8 http://www.ayocirebon.com/read/2018/04/11/1113/ojk-cirebon-sebutbmt-global-insani-ilegal, "OJK Cirebon Sebut BMT Global Insani Ilegal," $11 / 4 / 2018$, diakses 18/5/2019.

9 http:/ / www.ayocirebon.com/read/2018/04/11/1113/ojk-cirebon-sebutbmt-global-insani-ilegal.

10 Suhrawardi K. Lubis, Hukum Ekonomi Islam (Jakarta: Sinar Grafika, 2000), hlm. 114 .

11 Buchari Alma dan Donni Juni Priansa, Manejemen Bisnis Syari'ah (Bandung: Alfabeta, 2009), hlm. 18. 
lembaga keuangan yang lahir sebagai pilihan yang menggabungkan konsep maal dan tamwil dalam satu kegiatan lembaga. Jika konsep maal dimaksudkan untuk menghimpun dan menyalurkan dana untuk zakat, infak dan shadaqah (ZIS) secara produktif, maka konsep tamwil dimaksudkan sebagai kegiatan bisnis produktif yaitu mendapatkan keuntungan khususnya pada masyarakat menengah ke bawah (mikro). Kehadiran BMT dalam hal ini berarti menjalankan misi ekonomi syariah sekaligus mengemban tugas ekonomi kerakyatan dengan meningkatkan ekonomi mikro. ${ }^{12}$

BMT merupakan lembaga yang tidak hanya berorientasi bisnis tetapi juga sosial, dan lembaga yang tidak melakukan pemusatan kekayaan pada sebagian kecil orang tetapilembaga yang mendistribusi kekayaan secara merata dan adil. BMT juga merupakan lembaga keuangan syariah (LKS) yang jumlahnya paling banyak dibanding LKS lainnya. Sebagai organisasi bisnis, BMT mengembangkan usahanya melalui simpan pinjam sebagaimana perbankan, yakni menghimpun dana anggota dan calon anggota (nasabah) serta menyalurkannya pada sektor ekonomi halal dan menguntungkan. Sementara sebagai organisasi sosial, BMT turut mengelola dana zakat, infak, dan sedekah (ZIS).

BMT merupakan bagian dari LKM. Pada dasarnya LKM bertujuan untuk meningkatkan akses pendanaan skala mikro bagi masyarakat; membantu peningkatan pemberdayaan ekonomi dan produktivitas masyarakat; dan membantu peningkatan pendapatan dan kesejahteraan masyarakat; terutama masyarakat miskin dan/ atau berpenghasilan rendah. Tidak jauh berbeda dengan tujuan LKM, BMT pun demikian. ${ }^{13}$ Terlebih BMT merupakan LKM syariah yang

12 Novita Dewi Masyitoh, Analisis Normatif Undang-Undang No. 1 Tahun 2013 tentang Lembaga Keuangan Mikro (LKM) atas Status Badan Hukum dan Pengawasan Baitul Maal Wat Tamwil (BMT), Economica: Jurnal Ekonomi Islam, 5, 2 (2014), hlm. 18.

13 Dalam beberapa kasus, tujuan semacam ini boleh jadi sulit tercapai. Hasil penelitian Fitriani Prastiawati dan Emile Satia Darma misalnya, menunjukkan bahwa pembiayaan BMT pada pedagang pasar tradisional yang menjadi anggota BMT di Bantul ternyata tidak berpengaruh signifikan terhadap persepsi mereka tentang perkembangan usaha dan peningkatan kesejahteraannya, walaupun arahnya sudah benar positif. BMT sudah 
tujuannya tidak hanya keuntungan di dunia, tapi juga di akhirat.

Dalam kategori Bank Indonesia, LKM dibagi menjadi dua, yaitu LKM Bank dan LKM non Bank. LKM Bank terdiri dari BRI Unit Desa, BPR, dan Badan Kredit Desa (BKD). Sedangkan LKM non Bank terdiri dari Koperasi Simpan Pinjam (KSP), lembaga dana kredit pedesaan, BMT, lembaga swadaya masyarakat (LSM), arisan, pola pembiayaan grameen, pola pembiayaan ASA, kelompok swadaya masyarakat (KSM), credit union, dan lain-lain. ${ }^{14}$

Status hukum BMT dapat dikelompokkan menjadi tiga: pertama, koperasi (Koperasi Pondok Pesantren/Kopotren, Koperasi Simpan Pinjam/KSP, Koperasi Serba Usaha/ KSU, Koperasi BMT/ KBMT, $\mathrm{KJKS}$ ); kedua, yayasan (walaupun penggunaan status hukum yayasan bagi BMT tidak sesuai dengan Buku Panduan BMT yang dikeluarkan oleh Pusat Inkubasi Bisnis Usaha Kecil atau PINBUK) dan perseroan terbatas; ketiga, belum memiliki status badan hukum. BMT yang belum memiliki status badan hukum adalah BMT berbentuk kelompok swadaya masyarakat (KSM) atau lembaga swadaya masyarakat (LSM). Penggunaan KSM dan LSM mengacu pada buku panduan BMT yang dikeluarkan oleh PINBUK bahwa BMT dapat didirikan dalam bentuk swadaya masyarakat atau koperasi. ${ }^{15}$

PINBUK mengambil peran dalam pembangunan sosial ekonomi dengan strategi menumbuh-kembangkan kelembagaan swadaya masyarakat BMT yang dapat menjangkau dan melayani lebih banyak unit usaha mikro dengan pendekatan yang profesional, terintegrasi, dan tidak bertentangan dengan kaidah syariah dan agama apapun. Dalam perkembangannya, PINBUK turut memfasilitasi pembentukan LKM Syariah (LKMS), Koperasi Syariah (KSPPS), Badan Layanan

berperan positif terhadap perkembangan usaha dan peningkatan kesejahteraan, namun terlalu kecil atau tidak signifikan. Fitriani Prastiawati dan Emile Satia Darma, "Peran Pembiayaan Baitul Maal Wat Tamwil terhadap Perkembangan Usaha dan Peningkatan Kesejahteraan Anggotanya dari Sektor Mikro Pedagang Pasar Tradisional”, Jurnal Akuntansi dan Investasi, 17, 2 (2016), hlm. 206.

14 Neni Sri Imaniyati, Aspek-aspek Hukum BMT (Baitul Maal wa Tamwil) (Bandung: Citra Aditya Bakti, 2010), hlm. 96.

15 Sanjaya, "Implementasi Undang-undang Nomor 1 Tahun 2013”, hlm. 50. 
Umum Daerah Sektor Keuangan (BLUD), Badan Usaha Milik Desa (BUMDES), dan Lembaga Keuangan Mikro (LKM) lainnya. ${ }^{16}$ PINBUK hingga kini masih aktif, khususnya dalam pengembangan BMT.

Salah satu aturan tentang status badan hukum BMT ialah Surat Keputusan Menteri Dalam Negeri RI, Dirjen Pembangunan Daerah Nomor 538/PKKN/IV/1997 tanggal 14 April 1997 tentang Status Badan Hukum untuk Lembaga Keuangan Syariah. Menurut ketentuan tersebut, alternatif status badan hukum BMT antara lain Unit Usaha Otonom dari sebuah KUD (Koperasi Unit Desa) yang telah ada, KUD (Koperasi Unit Desa) itu sendiri, jika BMT layak secara permodalan dan kelembagaan, atau sebagai unit usaha otonom dari koperasi yang telah ada seperti koperasi pesantren dan sebagainnya, dan koperasi simpan pinjam syariah. ${ }^{17}$

BMT dengan badan hukum koperasi dapat memperoleh izin usaha dari Kementerian Koperasi dan UKM dan termasuk ke dalam KJKS atau Unit JKS Koperasi. Hal ini berdasarkan Keputusan Menteri Koperasi dan UKM Nomor 91/Kep/M.KUKM/IX/2004 tentang Petunjuk Pelaksanaan Kegiatan Usaha Koperasi Jasa Keuangan Syariah (KJKS). BMT berbadan hukum koperasi dapat bergerak di bidang pembiayaan, investasi, dan simpanan sesuai prinsip syariah. Kegiatan usaha KJKS dan UJKS Koperasi meliputi kegiatan penarikan/ penghimpunan dana dan penyaluran kembali dana tersebut dalam bentuk pembiayaan/piutang. Selain itu KJKS dan UJKS Koperasi dapat pula menjalankan kegiatan 'maal' atau kegiatan pengumpulan dan penyaluran dana zakat, infaq dan sodaqoh (ZIS). Dengan kata lain KJKS dan UJKS Koperasi ini memiliki sifat yang serupa dengan BMT. Sebagai lembaga keuangan syariah, KJKS atau BMT harus menjaga kredibilitas dan kepercayaan anggota pada khususnya dan masyarakat luas pada umumnya.

Untuk pengawasan BMT dalam bentuk KJKS, menurut Pasal 1 ayat (1) Peraturan Menteri Koperasi dan UKM Nomor 39/ Per/M.KUKM/XII/2007 tentang Pedoman Pengawasan Koperasi

16 https:/ / berita.pinbuk.id/category/bmt/, tanggal 18 Mei 2019.

17 Surat Keputusan Menteri Dalam Negeri RI, Direktur Jenderal Pembangunan Daerah Nomor 538/PKKN/IV/1997. 
Jasa Keuangan Syariah dan Unit Jasa Keuangan Syariah Koperasi disebutkan bahwa pengawasan adalah kegiatan pembinaan, pemantauan, pemeriksaan, dan penilaian kesehatan Koperasi Jasa Keuangan Syariah dan Unit Jasa Keuangan Syariah Koperasi oleh pemerintah dalam hal ini Menteri di tingkat pusat dan pejabat yang diberi wewenang menjalankan tugas pembantuan di tingkat daerah dengan tujuan agar pengelolaan KJKS dan UJKS Koperasi dilakukan secara baik dan terkendali sehingga menumbuhkan kepercayaan dari pihak terkait. Dengan kata lain, pengawasan BMT/KJKS dan UJKS Koperasi dilakukan oleh Menteri Koperasi di tingkat pusat dan pejabat yang diberi wewenang di tingkat daerah.

Pengawasan BMT/KJKS dilakukan oleh Kementerian Koperasi dan UKM di mana domisili BMT berada. Pada tingkat kabupaten/ kota, pengawasan dilakukan oleh Dinas Koperasi dan UKM Kota/ Kabupaten, sedangkan di tingkat provinsi oleh Dinas Koperasi dan UKM Provinsi. Pengawasan oleh Kementerian Koperasi dan UKM memiliki standar yang berbeda dibandingkan dengan pengawasan lembaga keuangan bank lainnya yang dilakukan oleh OJK, dikarenakan koperasi adalah lembaga keuangan mikro yang dirintis dari kecil, dengan modal kecil dan pengelolaan tidak berstandar.

Selain dalam bentuk KJKS, sebagaimana yang sudah dipaparkan sebelumnya, BMT juga dapat berupa badan usaha yang dimiliki oleh yayasan atau berbadan hukum yayasan itu sendiri. Dengan demikian, status badan hukum yayasan yang memiliki BMT akan tunduk pada Undang-undang Nomor 28 Tahun 2004 tentang Perubahan atas Undang-Undang Nomor 16 Tahun 2001 tentang Yayasan (UU Yayasan Tahun 2004). Jika berbadan hukum yayasan, maka BMT merupakan badan hukum yang terdiri atas kekayaan yang dipisahkan dan diperuntukkan untuk mencapai tujuan tertentu di bidang sosial, keagamaan, dan kemanusiaan, yang tidak mempunyai anggota. Dengan demikian BMT hanya akan bergerak di bidang sosial saja (baitul maal), yaitu di bidang pengelolaan zakat, infaq, sedekah, dan wakaf. Dalam kegiatan maal ini, BMT tunduk pada Undang-undang Nomor 23 Tahun 2011 tentang Pengelolaan Zakat.

Apabila BMT berbentuk Kelompok Swadaya Masyarakat, maka 
BMT merupakan badan usaha tidak berbadan hukum yang dibentuk oleh masyarakat secara sukarela berdasarkan kesamaan aspirasi, kehendak, kebutuhan, kepentingan, kegiatan, dan tujuan untuk berpartisipasi dalam pembangunan ekonomi rakyat kecil. BMT dalam bentuk ini dianggap tunduk pada Undang-undang Nomor 17 Tahun 2013 tentang Organisasi Masyarakat (UU Ormas), dikarenakan didirikan dalam bentuk organisasi kemasyarakatan oleh masyarakat. Menurut UU Ormas, ormas yang menghimpun dan mengelola dana dari iuran anggota sebagaimana dimaksud dalam Pasal 37 ayat (1) huruf a wajib membuat laporan pertanggungjawaban keuangan sesuai dengan standar akuntansi secara umum atau sesuai dengan AD dan/atau ART. Ormas yang menghimpun dan mengelola bantuan/ sumbangan masyarakat sebagaimana dimaksud dalam Pasal 37 ayat (1) huruf b, wajib mengumumkan laporan keuangan kepada publik secara berkala.

Dengan demikian, dilihat dari landasan hukum dan status badan hukum, maka BMT di Indonesia dapat dikelompokkan sebagai berikut:

1. BMTdenganbentukbadanhukumkoperasi,lebih spesifik Koperasi Jasa Keuangan Syariah, tunduk pada Undang-undang Nomor 25 Tahun 1992 tentang Perkoperasian, Keputusan Menteri Negara Koperasi dan Usaha Kecil dan Menengah Nomor 91/Kep/M. KUKM/IX/2004 tentang Petunjuk Pelaksanaan Kegiatan Usaha Koperasi Jasa Keuangan Syari'ah, Peraturan Menteri Negara Koperasi dan Usaha Kecil dan Menengah 35.2/Per/M.KUKM/ $\mathrm{X} / 2007$ tentang Pedoman Standar Operasional Manajemen Koperasi Jasa Keuangan Syari'ah, Peraturan Menteri Negara Koperasi dan Usaha Kecil dan Menengah 39/Per/M.KUKM/ XII/ 2007 tentang Pedoman Pengawasan Koperasi Jasa Keuangan Syari'ah dan Unit Jasa Keuangan Syariah Koperasi, Peraturan Menteri Negara Koperasi Dan Usaha Kecil Dan Menengah RI Nomor 35.3/Per/M.Kukm/X/2007 tentang Pedoman Penilaian Kesehatan Koperasi Jasa Keuangan Syariah dan Unit Jasa Keuangan Syariah Koperasi, dan peraturan turunan terkait koperasi lainnya. 
2. BMT sebagai badan usaha milik yayasan atau berbadan hukum yayasan tunduk pada Undang-undang Nomor 28 Tahun 2004 tentang Yayasan.

3. BMT tidak berbadan hukum atau masih merupakan KSM tunduk pada UU Ormas.

Setelah terbit dan berlakunya UULKM, landasan hukum dan status hukum BMT dan keterlibatan OJK perlu untuk dibahas. Berdasarkan UULKM, maka BMT sebagai LKM paling sedikit harus berbadan hukum koperasi atau perseroan terbatas. Pasal 28 Ayat (1) dan (2) UULKM mengatur bahwa pembinaan, pengaturan, dan pengawasan LKM dilakukan oleh OJK. Dalam melakukan pembinaan, OJK melakukan koordinasi dengan kementerian yang menyelenggerakan urusan koperasi dan Kementerian Dalam Negeri. Karena itu dapat dipahami dalam hal pembinaan, LKM berada di bawah tiga otoritas yaitu OJK, Kementerian Koperasi dan UKM, dan Kementerian Dalam Negeri. Sementara untuk pengaturan dan pengawasan ialah absolut kewenangan OJK terhadap LKM.

UULKM mentransformasikan status kelembagaan BMT yang semula berada di bawah Kementerian Koperasi dan UKM, serta dapat secara bebas menggeliat dalam bentuk lain, seperti yayasan dan ormas/ KSM, kini hanya OJK yang secara ketat mengatur dan mengawasi BMT. Pendirian BMT juga tidak akan lagi dapat dilakukan secara sederhana dalam bentuk KSM misalnya, sebab kini harus berbadan hukum (koperasi atau PT). Setiap LKM yang menjalankan usahanya wajib memiliki status badan hukum yang harus dipilih yaitu antara badan hukum koperasi atau badan hukum PT. Sebelum menjalankan kegiatan usahanya, LKM harus memiliki izin usaha dari OJK, dan untuk memeroleh izin usaha LKM maka harus dipenuhi paling sedikit persyaratan tentang susunan organisasi dan kepengurusan, permodalan, kepemilikan, dan kelayakan rencana kerja. $^{18}$

LKM yang melakukan kegiatan usaha berdasarkan prinsip syariah wajib menggunakan akad yang sesuai dengan prinsip

18 Pasal 5 Ayat (1) dan Pasal 9 ayat (1) dan (2) UULKM. 
syari’ah. Kegiatan usaha penghimpunan simpanan dilakukan dengan menggunakan akad wadiah, akad mudharabah, atau akad lain yang tidak bertentangan dengan prinsip syari'ah serta disetujui oleh OJK. Kegiatan usaha penyaluran pinjaman atau pembiayaan dilakukan dengan menggunakan akad mudharabah, akad musyarakah, akad murabahahatau akad lain yang tidak bertentangan dengan prinsip syari'ah serta disetujui oleh OJK. ${ }^{19}$

LKM berbadan hukum koperasi tidak hanya harus tunduk pada rezim Kementerian Koperasi dan UKM, tetapi juga rezim OJK. ${ }^{20}$ Cakupan wilayah usaha suatu LKM berada dalam satu wilayah desa/kelurahan, kecamatan, atau kabupaten/kota. ${ }^{21}$ Pembinaan dan pengawasan LKM didelegasikan kepada pemerintah daerah Kabupaten/kota atau kepada pihaklain jika pemerintah daerah kabupaten/ kota belum siap. ${ }^{22}$ Dalam rangka pembinaan dan pengawasan, OJK melakukan pemeriksaan terhadap LKM. ${ }^{23}$

Pasal 39 UULKM menjadi dasar bagi BMT untuk tunduk pada UULKM. Pasal tersebut menyatakan pada saat UULKM berlaku maka Bank Desa, Lumbung Desa, Bank Pasar, Bank Pegawai, Badan Kredit Desa (BKD), Badan Kredit Kecamatan (BKK), Kredit Usaha Rakyat Kecil (KURK), Lembaga Perkreditan Kecamatan (LPK), Bank Karya Produksi Desa (BKPD), Badan Usaha Kredit Pedesaan (BUKP), Baitul Maal wa Tamwil (BMT), Baitul Tamwil Muhammadiyah (BTM), dan/atau lembaga-lembaga lainnya wajib memperoleh izin usaha dari OJK, kecuali LKM yang tunduk pada rezim hukum adat. OJK, Kementerian Koperasi dan UKM, dan Kementerian Dalam Negeri melakukan inventarisasi LKM yang belum berbadan hukum paling lambat 2 tahun sejak UULKM berlaku (Pasal 40 UULKM). Tahun 2019 ini sebanyak 35 LKM yang sudah terdaftar di OJK. ${ }^{24}$

19 Pasal 12 Peraturan OJK Nomor 61 / POJK.05/2014 tentang Perizinan Usaha dan Kelembagaan Lembaga Keuangan Mikro.

20 Pasal 10 UULKM.

21 Pasal 16 ayat (1) UULKM.

22 Pasal 28 UULKM.

23 Pasal 31 UULKM.

24 https://www.ojk.go.id/id/kanal/iknb/Pages/LKM-Terdaftar-OJK.aspx, "Lembaga Keuangan Mikro yang Terdaftar di OJK", diakses 18/5/2019. 
Dengan demikian, sudah jelas bahwa BMT kini harus memeroleh izin usaha dari OJK dengan status badan hukum koperasi atau perseroan terbatas. Tetapi untuk LKM, dalam hal ini BMT yang berbadan hukum koperasi hanya bisa beroperasi sampai kabupaten/ kota. ${ }^{25}$ Jika wilayahnya sudah melebihi dari kabupaten/kota, maka LKM (termasuk pula BMT) harus bertransformasi menjadi bank. ${ }^{26}$ Ketika keharusan untuk bertransformasi ini diimplementasikan, maka sebagaimana pada umumnya, bentuk badan hukum sebuah bank adalah perseroan terbatas. Karena itu, BMT yang tadinya berbadan hukum koperasi, kemudian wilayah cakupan usahanya melebihi kabupaten/kota, BMT harus bertransformasi menjadi bank (misal bank perkreditan rakyat syariah), dan merubah status badan hukumnya menjadi perseroan terbatas (PT). LKM dengan badan hukum PT, paling sedikit 60\% sahamnya dimiliki oleh Pemerintahan Kabupaten/kota atau badan usaha milik desa/kelurahan, sisanya oleh warga negara Indonesia dan koperasi. ${ }^{27} \mathrm{Hal}$ ini tentu menjadi dilema tersendiri untuk BMT. ${ }^{28}$

Hal yang perlu dipertegas ialah bahwa setelah diberlakukannya UULKM, peran OJK kini diperkuat, sebab OJK-lah yang berwenang melakukan pembinaan, pengaturan, dan pengawasan terhadap LKM (termasuk BMT). BMT kini tidak dapat hanya sekadar menjadi BMT (tidak berbadan hukum/tidak berizin usaha), tetapi harus berbadan hukum dan berizin usaha. Namun dalam hal pembinaan, OJK memang masih melakukan koordinasi dengan kementerian yang menyelenggarakan urusan koperasi dan Kementerian Dalam Negeri. ${ }^{29}$ Sementara dalam pengawasan dan pengaturan telah menjadi kewenangan absolut OJK untuk LKM (termasuk BMT).

Sekilas memang ketika mendengar kata koperasi, terutama BMT sebagai koperasi/berbadan hukum koperasi, maka masyarakat luas akan langsung berpikir bahwa menjadi tugas Kementerian Koperasi

25 Pasal 31 UULKM.

26 Pasal 27 UULKM.

27 Pasal 5 UULKM.

28 Masyitoh, “Analisis Normatif Undang-undang”, hlm. 33.

29 Pasal 28 UULKM. 
dan Usaha Kecil dan Menengah untuk pengawasan, pengaturan, dan pembinaan. Nyatanya tidak demikian, sebab BMT merupakan lembaga keuangan mikro ${ }^{30}$ syariah, di mana pengawasan, pengaturan, dan pembinaannya berada di bawah OJK. Meski demikian, OJK juga menyepakati nota kesepahaman dengan Kementerian Dalam Negeri dan Kementerian Koperasi dan Usaha Kecil Menengah tentang koordinasi pelaksanaan Undang-Undang Nomor 1 Tahun 2013 tentang Lembaga Keuangan (UU LKM) atau tentang pembinaan LKM berbadan hukum koperasi. ${ }^{31}$

\section{Contoh Kasus BMT Ilegal: BMT Global Insani}

BMT Global Insani berlokasi di Lurah, Plumbon, Cirebon, Jawa Barat berafiliasi dengan PT Surabraja Mandiri di Kabupaten Cirebon. PT Surabaja sendiri sedang dalam keadaan pailit. BMT ini melakukan penipuan terhadap setidaknya 4.300 nasabahnya. Modus BMT Global Insani yaitu dengan menawarkan investasi dalam bentuk jahe dan jabon dengan sistem bagi hasil dan melalui penyediaan jasa pemberangkatan haji dan umroh. ${ }^{32}$

Salah satu sistem kerja BMT Global Insani ialah menawarkan produk investasi al-Qiradh kepada masyarakat. Untuk per paket produk al-Qiradh dibanderol dengan nilai delapan juta rupiah. Dana yang terkumpul di BMT Global Insani tersebut kemudian disalurkan melalui PT Surabraja Mandiri yang bekerjasama dengan

30 Pasal 1 angka 1 UULKM: "LKM adalah lembaga keuangan yang khusus didirikan untuk memberikan jasa pengembangan usaha dan pemberdayaan masyarakat, baik melalui pinjaman atau pembiayaan dalam usaha skala mikro kepada anggota dan masyarakat, pengelolaan simpanan, maupun pemberian jasa konsultasi pengembangan usaha yang tidak semata-mata mencari keuntungan".

31 Tania Theresia Siregar, "Pengawasan Otoritas Jasa Keuangan terhadap Koperasi Simpan Pinjam Ilegal terkait Investasi Ilegal dan Usaha Mikro Kecil Menengah (UMKM) dalam Mencegah Praktek Pengumpulan Dana Masyarakat Secara Ilegal”, Skripsi, Fakultas Hukum Universitas Sumatera Utara, 2018, hlm. 86.

32 https://regional.kontan.co.id/news/rugikan-nasabah-rp-77-miliar-polisitetapkan-6-tersangka-penipuan-bmt-global-insani, "Rugikan Nasabah Rp 77 Miliar, Polisi Tetapkan 6 Tersangka Penipuan BMT Global Insani", $31 / 1 / 2019$, diakses 18/5/2019. 
pihak lain, disalurkan untuk mengelola perkebunan jabon dan jahe seluas 116 hektare di Sukabumi. Sebelum perkara calon jamaah haji yang terdaftar di Global Insani, pada tahun 2017 sempat muncul gejolak lantaran investor Global Insani tidak mendapatkan hasil yang dijanjikan selama tiga tahun. Investor tidak mendapat bagi hasil dan pokok sesuai yang diperjanjikan akibat kegagalan panen yang dialami. Sementara sebagian investor tersebut merencanakan dana bagi hasil dan pokok untuk beribadah umroh dan melakukan pelunasan biaya porsi haji. ${ }^{33}$

Dalam perkembangannya, Satgas Waspada Investasi memanggil pengurusBMT GlobalInsanisebanyaktigakali. Darihasilpemanggilan tersebut, OJK menyimpulkan bahwa Global Insani dinyatakan ilegal karena tidak terdaftar pada OJK. BMT Global Insani tidak berada di bawah pengawasan OJK, dan berdasarkan informasi Dinas Koperasi dan UMKM Kabupaten Cirebon, tidak ada izin usaha yang diberikan oleh Dinas kepada BMT Global Insani. Pada Maret 2017, Pengadilan Niaga menyatakan BMT Global Insani pailit dengan putusan Nomor 12 / Pdt.Sus-Pailit/2017 / PN.Niaga.Jkt.Ps. ${ }^{34}$

\section{Peran OJK dalam Perlindungan Nasabah BMT Ilegal}

Ketentuan mengenai BMT berbadan hukum koperasi adalah bentuk yang tidak serupa sebagaimana koperasi dalam UndangUndang Perkoperasian, sehingga BMT selaku LKM meskipun secara kelembagaan berbadan hukum koperasi namun untuk segala pengaturan dan operasionalnya tunduk pada ketentuan UULKM dan Peraturan Otoritas Jasa Keuangan. Kebijakan pemerintah terkait regulasi BMT yang diatur dalam beberapa Peraturan Perundangundangan seperti Undang-undang Perkoperasian, UULKM dan Peraturan OJK saat ini menjadikan BMT sebagai lembaga keuangan

33 https: / / news.detik.com/ berita-jawa-barat/d-3961872/global-insanicirebon-tarik-investasi-dari-jemaah-ojk-ilegal, "Global Insani Cirebon Tarik Investasi dari Jemaah, OJK: Ilegal”, 9/4/2018, diakses 26/7/2019.

34 https:// news.detik.com/berita-jawa-barat/d-3961872/global-insanicirebon-tarik-investasi-dari-jemaah-ojk-ilegal. 
yang secara operasional lebih dekat kepada perbankan. ${ }^{35}$

BMT yang tidak ilegal atau memiliki izin dari OJK dan berbadan hukum koperasi, perlindungan hukum nasabah dapat berlandaskan Undang-undang Nomor 25 Tahun 1992 tentang Koperasi, khususnya Pasal 54 tentang Penyelesaian. ${ }^{36}$ Dalam kasus investasi ilegal yang dilakukan oleh BMT tidak berizin, OJK mengambil peran. Meski BMT tersebut tidak berizin, sehingga tidak berada di bawah pengawasan OJK, tetapi untuk perbuatan melawan hukum yang merugikan nasabah, OJK akan mengambil langkah penanganan antara lain melalui Satgas Waspada Investasi.

Satuan Tugas Penanganan Dugaan Tindakan Melawan Hukum di Bidang Penghimpunan Dana Masyarakat dan Pengelolaan Investasi (Satgas Waspada Investasi) dibentuk berdasarkan Keputusan Dewan Komisioner Otoritas Jasa Keuangan Nomor 01/KDK.01/ 2016 tanggal 1 Januari 2016, merupakan hasil kerjasama beberapa instansi terkait, meliputi Regulator sebagai berikut: Otoritas Jasa Keuangan, Kementerian Perdagangan Republik Indonesia, Badan Koordinasi Penanaman Modal, Kementerian Koperasi dan Usaha Kecil dan Menengah Republik Indonesia, Kementerian Komunikasi dan Informasi Republik Indonesia, dan Penegak Hukum yang terdiri dari Kejaksaan Republik Indonesia dan Kepolisian Negara Republik Indonesia.

Satgas Waspada Investasi merupakan wadah koordinasi antar regulator, instansi pengawas, instansi penegak hukum dan pihak lain yang terkait dalam hal penanganan dugaan tindakan melawan hukum di bidang penghimpunan dana masyarakat dan pengelolaan investasi. Sampai dengan 11 Juni 2016, masyarakat telah menyampaikan adanya permintaan informasi dan/atau pertanyaan terhadap legalitas 430 perusahaan yang menawarkan investasi kepada masyarakat. Dari jumlah itu terdapat 374 tawaran investasi yang berkaitan dengan

35 Fadilah Mursid, "Kebijakan Regulasi Baitul Maal Wa Tamwil (BMT) di Indonesia”, Nurani: Jurnal Kajian Syari'ah dan Masyarakat, 18, 2 (2018), hlm. 27.

36 Ade Fatonah, "Dampak Pembekuan Produk Sajadah Ekstra terhadap Kondisi Ekonomi Nasabah di KSPPS BMT CSI Syariah Sejahtera”, Inklusif, 3, 1 (2018), hlm. 10. 
keuangan (antara lain emas, forex, e-money, e-commerce, investasi haji dan umroh) sementara sisanya sebanyak 56 tawaran berupa investasi di bidang properti, tanaman, komoditas dan perkebunan. Setelah dilakukan penelitian lebih lanjut, seluruh perusahaan yang menawarkan investasi dan diragukan aspek legalitasnya tersebut, ternyata tidak satupun yang terdaftar di OJK. Dari jumlah tersebut, terdapat 388 tawaran dari perusahaan yang sama sekali tidak memiliki kejelasan izin beroperasi, 13 tawaran dari perusahaan yang memiliki SIUP/TDP tetapi tidak memiliki izin yang terkait dengan investasi yang dilakukan, 23 tawaran yang menjadi lingkup perdagangan komoditas, dan enam tawaran dari perusahaan yang berbentuk koperasi. ${ }^{37}$

OJK melakukan prosedur perlindungan nasabah yang menjadi korban dari BMT ilegal ialah salah satunya dengan melalui Satgas Waspada Investasi. Hal lain yang dapat dilakukan nasabah ialah dengan berkonsultasi terkait penawaran investasi keuangan yang dianggap mencurigakan (termasuk terkait BMT tanpa izin) ke Layanan Konsumen OJK dan Satgas Waspada Investasi. Ini artinya rezim perlindungan konsumen pelaku usaha jasa keuangan juga tetap berlaku untuk nasabah korban BMT ilegal. Perlindungan konsumen untuk BMT ilegal tidak jauh berbeda dengan perlindungan konsumen nasabah perbankan dan konsumen lembaga keuangan non-bank pada umumnya.

Dalam perkara BMT ilegal, OJK dan Satgas Waspada Investasi akan melakukan penyelidikan. Salah satu hasilnya ialah fakta bahwa BMT Global Insani bergerak tanpa izin. Penyidikan dilakukan dengan memerhatikan dua aspek: aspek pengamanan aset dan aspek kejelasan pihak-pihak yang bertanggung jawab atas kegiatan BMT ilegal. Dalam kasus BMT Global Insani, polisi menetapkan enam tersangka yang terdiri dari direktur utama, komisaris PT, direktur utama 1 PT Surabraja, dua direktur utama, direktur BMT Global Insani, dan manager operasional BMT Global Insasni.

Kasus investasi ini dapat dikenakan Pasal 59 Undang-undang

37 https://waspadainvestasi.ojk.go.id/news/ojk-perkuat-satgas-waspadainvestasi, "OJK Perkuat Satgas Waspada Investasi”, 21/6/2016, diakses $18 / 5 / 2019$. 
Nomor 21 tentang Perbankan Syariah. ${ }^{38}$ Pada kasus BMT Global Insani, tersangka dilaporkan ke Bareskrim atas dugaan tindak pidana melakukan penghimpunan dana berdasarkan prinsip syariah tanpa izin usaha dengan dikenakan Pasal 5 ayat (1) ${ }^{39}$ juncto Pasal 22 UU RI Nomor 21 Tahun 2008 tentang Perbankan Syariah ${ }^{40}$ juncto Pasal 55 KUHP juncto Pasal 56 KUHP. ${ }^{41}$ Ancaman hukuman paling singkat lima tahun dan maksimal 15 tahun. ${ }^{42}$ BMT ilegal dapat dikenakan pelanggaran pasal dalam UU Perbankan Syariah. Hal ini dikarenakan pada Pasal 59 misalnya, disebutkan bahwa ketentuan ini tidak hanya diperuntukkan perbankan syariah, tetapi juga individu (masyarakat pada umumnya/setiap orang) termasuk badan hukum. Dengan demikian, setiap orang yang melakukan kegiatan penghimpunan dana dalam bentuk simpanan atau investasi berdasarkan prinsip

38 Pasal 59 (1): “Setiap orang yang melakukan kegiatan usaha Bank Syariah, UUS, atau kegiatan penghimpunan dana dalam bentuk Simpanan atau Investasi berdasarkan Prinsip Syariah tanpa izin usaha dari Bank Indonesia sebagaimana dimaksud dalam Pasal 5 ayat (1) dan Pasal 22 dipidana dengan pidana penjara paling singkat 5 (lima) tahun dan paling lama 15 (lima belas) tahun dan pidana denda paling sedikit Rp10.000.000.000,00 (sepuluh miliar rupiah) dan paling banyak Rp200.000.000.000,00 (dua ratus miliar rupiah)".

39 Pasal 5 (1): "Setiap pihak yang akan melakukan kegiatan usaha Bank Syariah atau UUS wajib terlebih dahulu memperoleh izin usaha sebagai Bank Syariah atau UUS dari Bank Indonesia”.

40 Pasal 22: "Setiap pihak dilarang melakukan kegiatan penghimpunan dana dalam bentuk Simpanan atau Investasi berdasarkan Prinsip Syariah tanpa izin terlebih dahulu dari Bank Indonesia, kecuali diatur dalam undangundang lain”.

41 Pasal 55 ayat (1) KUHP: Dipidana sebagai pelaku tindak pidana: 1) mereka yang melakukan, yang menyuruh melakukan, dan yang turut serta melakukan perbuatan; 2) mereka yang dengan memberi atau menjanjikan sesuatu dengan menyalahgunakan kekuasaan atau martabat, dengan kekerasan, ancaman atau penyesatan, atau dengan memberi kesempatan, sarana atau keterangan, sengaja menganjurkan orang lain supaya melakukan perbuatan. Ayat ((2): Terhadap penganjur, hanya perbuatan yang sengaja dianjurkan sajalah yang diperhitungkan, beserta akibat-akibatnya. Pasal 56 KUHP: dipidana sebagai pembantu kejahatan: 1) mereka yang sengaja memberi bantuan pada waktu kejahatan dilakukan; 2) mereka yang sengaja memberi kesempatan, sarana atau keterangan untuk melakukan kejahatan.

42 https:// regional.kontan.co.id/news/rugikan-nasabah-rp-77-miliar-polisitetapkan-6-tersangka-penipuan-bmt-global-insani. 
syariah tanpa izin dari OJK, maka akan dipidana berdasarkan Pasal 59 tersebut.

Dengan berkoordinasi dengan Kementerian Perdagangan RI, OJK juga melakukan pengawasan dan pemeriksaan atas dugaan penyalahgunaan Surat Izin Usaha Perdagangan (SIUP) BMT Global Insani. Majelis Ulama Indonesia (MUI) juga menjadi pihak yang dilibatkan untuk memeriksa apakah produk yang dikeluarkan BMT ilegal ini sesuai dengan prinsip syariah atau tidak.

Meski OJK tetap berperan dalam perlindungan nasabah korban BMT tidak berizin usaha, tetapi urgensi izin usaha atau legalitas lembaga keuangan (termasuk lembaga keuangan mikro/BMT) menjadi sangatlah penting. Hal iniuntuk mencegah tindakan melawan hukum yang dilakukan oleh BMT ilegal tersebut. OJK menghimbau masyarakat untuk memastikan BMT yang menawarkan investasi memiliki izin usaha dari otoritas yang berwenang sesuai dengan kegiatan usaha yang dijalankan/berada di bawah pengawasan OJK dan memastikan bahwa BMT memiliki izin dalam menawarkan produk investasi dan produk lainnya atau tercatat sebagai mitra pemasar. Hal lain yang perlu diperhatikan ialah bagaimana keterlibatan DPS pada BMT tersebut.

Demikian berdasarkan UULKM, BMT kini harus mengantongi izin usaha dari Kementerian Keuangan dan UKM untuk yang berbadan hukum koperasi, tetapi pembinaan, pengaturan dan pengawasannya berada di bawah OJK, sehingga OJK pun berhak atas data BMT yang berbadan hukum koperasi tersebut. BMT yang tidak terdaftar di OJK beresiko melakukan perbuatan melawan hukum, seperti penipuan melalui investasi atau produk yang tidak sesuai syariah. Nasabah yang menjadi korban BMT ilegal dapat melapor ke OJK, sehingga OJK akan menangani perkara BMT ilegal tersebut berdasarkan rezim perlindungan konsumen dan peraturan perundang-undangan lain yang berkaitan dengan tindakan BMT tanpa izin usaha.

Dalam UULKM juga dijelaskan bahwa untuk perlindungan penyimpan dari masyarakat, OJK berwenang melakukan tindak pencegahan kerugian penyimpan dan masyarakat pada umumnya. Kewenangan OJK dilakukan dengan memberikan informasi dan 
edukasi (literasi) kepada masyarakat atas karakteristik dan kegiatan usaha BMT, meminta LKM untuk menghentikan kegiatannya apabila kegiatan tersebut merugikan masyarakat, dan tindakan lainnya. UULKM mengamantkan agar OJK menyediakan, memfasilitasi, dan membuat mekanisme layanan pengaduan bagi masyarakat yang dirugikan oleh LKM, termasuk BMT yang tidak berizin. ${ }^{43}$ OJK juga membentuk Investor Protection Fund (IPF), menerbitkan Peraturan Nomor 1/POJK.07/2013 tentang Perlindungan Konsumen Sektor Jasa Keuangan, dan memfasilitasi penyelesaian sengketa di sektor jasa keuangan yang terdiri dari pelaksanaan internal dispute resolution oleh lembaga jasa keuangan dan pelaksanaan external dispute resolution (melalui lembaga alternatif). ${ }^{44}$

OJK telah mengesahkan peraturan khusus untuk lembaga keuangan mikro, termasuk di dalamnya BMT, yakni antara lain sebagai berikut: ${ }^{45}$

1. POJK Nomor 62 / POJK.05/ 2015 tentang tentang Perubahan Atas Peraturan Otoritas Jasa Keuangan Nomor 13/ POJK.05 / 2014 tentang Penyelenggaraan Usaha Lembaga Keuangan Mikro.

2. POJK Nomor 61/POJK.05/2015 tentang Perubahan atas Peraturan Otoritas Jasa Keuangan Nomor 12/ POJK.05 / 2014 Tentang Perizinan Usaha Lembaga Keuangan Mikro.

3. POJK Nomor 14/POJK.05/ 2014 tentang Perubahan atas Peraturan Otoritas Jasa Keuangan Nomor 12/POJK.05/2014 Tentang Pembinaan dan Pengawasan Lembaga Keuangan Mikro.

Peraturan-peraturan di atas tidak lain bertujuan untuk meningkatkan pengawasan OJK terhadap LKM dan menyediakan perlindungan nasabah LKM yang lebih optimal. Dapat dikatakan bahwa peran OJK dalam pengawasan BMT lebih luas dari institusi lain (seperti Kementerian Koperasi dan Usaha Kecil dan Menengah),

43 Pasal 25 dan 26 UULKM.

44 Dian Husna Fadlia dan Yunanto, "Peran Otoritas Jasa Keuangan dalam Perlindungan Hukum Bagi Investor atas Dugaan Investasi Fiktif”, Jurnal Law Reform, 11, 2 (2015), hlm. 215.

45 Direktorat Lembaga Keuangan Mikro Otoritas Jasa Keuangan, Frequently Asked Question (FAQ) Lembaga Keuangan Mikro (LKM), https: / /www. ojk.go.id/Files/box/LKM/faq-lkm.pdf diakses 26/ 7/2019. 
yakni OJK juga berwenang untuk melakukan penyelidikan, perlindungan konsumen, serta pelaporan/tuntutan pidana terhadap LKM, dalam hal ini BMT. Artinya kewenangan yang dimiliki OJK mencakup segala aspek. ${ }^{46}$ Tidak hanya aspek kelembagaan BMT sebagai Koperasi namun juga aspek perlindungan konsumen BMT, khususnya BMT ilegal.

Bentukpengawasan OJKterhadapLKM(termasukBMT) adalah ${ }^{47}$ perlindungan konsumen; pengawasan melalui laporan keuangan; pemeriksaan; penyidikan; menetapkan sanksi administratif; memberikan atau mencabut izin usaha, izin orang perseorangan, efektifnya pernyataan pendaftaran, surat tanda terdaftar, persetujuan melakukan kegiatan usaha, pengesahan, persetujuan atau penetapan pembubaran, dan penetapaan lain sebagaimana dimaksud dalam peraturan perundang-undangan sektor jasa keuangan; melakukan tuntutan pidana terhadap LKM yang menjalankan usaha tanpa izin, pihak yang memberikan informasi mengenai pinjaman dan simpanan di luar ketentuan yang diperbolehkan, dan LKM termasuk BMT memberikan keterangan palsu.

Bentuk pengawasan OJK berupa pemeriksaan ialah pemeriksaan langsungberdasarkanhasilanalisislaporanberkalaLKM. ${ }^{48}$ Pengawasan melalui laporan keuangan dilakukan guna memeriksa apakah ada kegiatan usaha LKM yang menyimpang dari peraturan perundangundangan yang menimbulkan risiko bagi keberlangsungan usaha LKM dan/atau kepentingan nasabah dalam kegiatan penyaluran pinjaman atau pembiayaan dan pengelolaan simpanan. Pengaduan atau laporan dapat disampaikan masyarakat terkait dugaan penyelenggaraan kegiatan usaha dari LKM menyimpang. Di samping itu, OJK juga

46 Sanjaya, "Implementasi Undang-undang Nomor 1 Tahun 2013”, hlm. 112.

47 Istiqomah, "Kewenangan Mengatur dan Mengawasi Otoritas Jasa Keuangan terhadap Baitul Maal Wa Tamwil (Studi Analisis terhadap Undang-undang Nomor 21 Tahun 2011 Tentang Otoritas Jasa Keuangan), Skripsi, Fakultas Syariah Universitas Islam Negeri Maulana Malik Ibrahim, 2014, hlm. 88.

48 Reza Driandra, "Pelaksanaan Fungsi Pengaturan dan Pengawasan Terhadap Lembaga Keuangan Mikro di Lampung Oleh Otoritas Jasa Keuangan”, Tesis, Fakultas Hukum Universitas Lampung, Bandar Lampung, 2018, hlm. 101. 
bertugas untuk melaksanakan langkah-langkah penyehatan terhadap LKM yang mengalami kesulitan likuiditas dan solvabilitas yang membahayakan keberlangsungan usaha. ${ }^{49}$ Karena itu, izin usaha LKM (termasuk BMT) menjadi penting, guna BMT memperoleh pembinaan dan pengawasan langsung dari OJK, khususnya dalam hal penyehatan dan perlindungan konsumen.

Peraturan perundang-undangan di bidang LKM telah memberikan OJK peran yang signifikan dalam melakukan pengawasan terhadap LKM dan meningkatkan perlindungan konsumen nasabah LKM (termasuk di dalamnya BMT). Dalam POJK Nomor 14/ POJK.05/2014 diatur bahwa untuk dapat melaksanakan fungsi dan tugas pembinaan dan pengawasan LKM, Pemerintah Daerah Kabupaten/Kota melakukan persiapan sumber daya manusia dan infrastruktur, antara lain dengan menunjuk pegawai pemerintah daerah kabupaten/kota untuk melaksanakan pembinaan dan pengawasan LKM tersebut. Pihak lain juga ditunjuk sesuai persyaratan dalam POJK tersebut. ${ }^{50}$ Meski demikian, di tataran pelaksanaan, OJK tidak dapat melakukannya secara maksimal, sebab OJK tidak dapat menjangkau seluruh LKM di Indonesia, utamanya di pelosok desa.

Dengan demikian, peran OJK dalam pengawasan BMT telah diperluas, dari aspek kelembagaan BMT hingga aspek perlindungan konsumen BMT, khususnya BMT ilegal. Hal-hal semacam ini perlu untuk disosialisasikan secara meluas kepada masyarakat, agar masyarakat mengetahui apa yang harus dilakukan khususnya ketika dirugikan oleh BMT ilegal. Selainitu, upaya preventif dan menyeluruh oleh OJK dalam mengawasi BMT ilegal juga perlu ditingkatkan, agar tidak ada lagi BMT lainnya yang merugikan masyarakat. ${ }^{51}$

49 Pasal 5 ayat (1) Peraturan Otoritas Jasa Keuangan Nomor 14/ POJK.05 / 2014 tentang Pembinaan dan Pengawasan Lembaga Keuangan Mikro.

50 Pasal 3 Peraturan Otoritas Jasa Keuangan Nomor 14/ POJK.05 / 2014 tentang Pembinaan dan Pengawasan Lembaga Keuangan Mikro.

51 Hal ini penting karena keberadaan BMT sebenarnya merupakan salah satu kontribusi bagi suksesnya proses pembangunan, sehingga pelan tapi pasti dapat mengikis atau mengurangi jumlah penduduk miskin di Indonesia. Namun demikian, dengan cukup banyaknya BMT Palsu, yaitu BMT-BMT yang hanya sekadar mencari keuntungan belaka yang jauh dari prinsip syariah, jelas merugikan masyarakat, dan karenanya perlu ditindak tegas. 


\section{E. Kesimpulan}

Artikel ini menyimpulkan, pertama, BMT sebagai LKM yang harus berbadan hukum dalam bentuk koperasi atau perseroan terbatas, mendapatkan pembinaan, pengaturan, dan pengawasan dari OJK. Dalam hal pembinaan, OJK perlu berkoordinasi dengan kementerian yang menyelenggerakan urusan koperasi dan Kementerian Dalam Negeri, dan karenanya LKM sesungguhnya berada di bawah tiga otoritas, yaitu OJK, Kementerian Koperasi dan UKM, dan Kementerian Dalam Negeri. Sedangkan dalam hal pengaturan dan pengawasan, OJK yang secara absolut berwenang. Kedua, dengan berlakunya UULKM, BMT wajib memperoleh izin usaha dari OJK, dan jika tidak, statusnya berarti ilegal. Berdasarkan UU Perbankan Syari'ah, BMT ilegal dapat dikenakan tindak pidana melakukan penghimpunan dana berdasarkan prinsip syariah tanpa izin usaha, sebagaimana terjadi pada BMT Global Insani. Ketiga, peran OJK dalam pengawasan BMT telah diperluas, dari aspek kelembagaan BMT hingga aspek perlindungan konsumen BMT, khususnya BMT ilegal. Perlindungan konsumen yang dapat dilakukan OJK ialah melalui mekanisme pengaduan, penyelidikan, hingga pelaporan dan penuntutan.

\section{Daftar Pustaka}

\section{Artikel/Buku/Laporan}

Alma, Buchari dan Donni Juni Priansa. Manejemen Bisnis Syari'ah. Bandung: Alfabeta, 2009.

Direktorat Lembaga Keuangan Mikro Otoritas Jasa Keuangan. "Frequently Asked Question (FAQ) Lembaga Keuangan Mikro (LKM)”. https: / / www.ojk.go.id/Files/box/LKM/ faq-lkm.pdf. Diakses 26/ $7 / 2019$.

Driandra, Reza. "Pelaksanaan Fungsi Pengaturan dan Pengawasan Terhadap Lembaga Keuangan Mikro di Lampung Oleh Otoritas Jasa Keuangan”. Tesis, Fakultas Hukum Universitas Lampung,

Dadan Muttaqien, "Urgensi Legalitas Lembaga Keuangan Mikro Syariah”, Millah: Jurnal Studi Agama, edisi khusus (2010), hlm. 196-197. 
Bandar Lampung, 2018.

Fadlia, Dian Husna dan Yunanto. "Peran Otoritas Jasa Keuangan dalam Perlindungan Hukum Bagi Investor atas Dugaan Investasi Fiktif”. Jurnal Law Reform, 11, 2 (2015): 207-215. DOI: 10.14710/ lr.v11i2.15768

Fatonah, Ade. "Dampak Pembekuan Produk Sajadah Ekstra terhadap Kondisi Ekonomi Nasabah di KSPPS BMT CSI Syariah Sejahtera”. Inklusif, 3, 1 (2018): 91-104. DOI: 10.24235/inklusif. v3i1.2830.g1658

Https:/ / berita.pinbuk.id/category/bmt/. Diakses 18/5/2019.

Https: / / finansial.bisnis.com/ read/20150121/90/393529/1kmbelum-berbadan-hukum-dianggap-ilegal-. "LKM Belum Berbadan Hukum Dianggap Ilegal”, 21/1/2015. Diakses $18 / 5 / 2019$.

Https: / / news.detik.com/berita-jawa-barat/ d-3961872/globalinsani-cirebon-tarik-investasi-dari-jemaah-ojk-ilegal. "Global Insani Cirebon Tarik Investasi dari Jemaah, OJK: Ilegal”, 9/4/2018. Diakses 26/7/2019.

Https: / / regional.kontan.co.id/ news / rugikan-nasabah-rp-77miliar-polisi-tetapkan-6-tersangka-penipuan-bmt-global-insani. "Rugikan Nasabah Rp 77 Miliar, Polisi Tetapkan 6 Tersangka Penipuan BMT Global Insani”, 31/1/2019. Diakses 18/5/2019. Https: / / waspadainvestasi.ojk.go.id/news / ojk-perkuat-satgaswaspada-investasi. "OJK Perkuat Satgas Waspada Investasi”, 21/6/2016. Diakses 18/5/2019.

Http: / / www.ayocirebon.com/ read/2018/04/11/1113/ojk-cirebonsebut-bmt-global-insani-ilegal. "OJK Cirebon Sebut BMT Global Insani Ilegal,” 11/4/2018. Diakses 18/5/2019.

Https: / / www.liputan6.com/bisnis/ read/3799067/ ojk-tindak-11kasus-penipuan-investasi-berkedok-koperasi. “'”JK Tindak 11 Kasus Penipuan Investasi Berkedok Koperasi”. Diakses $18 / 5 / 2019$.

Https: / / www.ojk.go.id/id/kanal/iknb/Pages/LKM-TerdaftarOJK.aspx. "Lembaga Keuangan Mikro yang Terdaftar di OJK”. Diakses 18/5/2019. 
Imaniyati, Neni Sri. Aspek-aspek Hukum BMT (Baitul Maal wa Tamwil). Bandung: Citra Aditya Bakti, 2010.

Istiqomah. "Kewenangan Mengatur dan Mengawasi Otoritas Jasa Keuangan terhadap Baitul Maal Wa Tamwil (Studi Analisis terhadap Undang-undang Nomor 21 Tahun 2011 tentang Otoritas Jasa Keuangan)”. Skripsi, Fakultas Syariah Universitas Islam Negeri Maulana Malik Ibrahim, 2014.

Kementerian Koperasi dan UKM. "Rekapitulasi Data Koperasi Berdasarkan Provinsi”. http://www.depkop.go.id/datakoperasi. Diakses 20/7/2019.

Lubis, Suhrawardi K. Hukum Ekonomi Islam. Jakarta: Sinar Grafika, 2000.

Masyitoh, Novita Dewi. "Analisis Normatif Undang-Undang No.

1 Tahun 2013 tentang Lembaga Keuangan Mikro (LKM) atas Status Badan Hukum dan Pengawasan Baitul Maal Wat Tamwil (BMT)". Economica: Jurnal Ekonomi Islam, 5, 2 (2014): 17-36. DOI: 10.21580/economica.2014.5.2.768

Mursid, Fadilah. "Kebijakan Regulasi Baitul Maal Wa Tamwil (BMT) di Indonesia”. Nurani: Jurnal Kajian Syari'ah dan Masyarakat, 18, 2 (2018): 9-30. DOI: 10.19109/nurani.v18i2.2486

Muttaqien, Dadan. "Urgensi Legalitas Lembaga Keuangan Mikro Syariah”. Millah: Jurnal Studi Agama, edisi khusus (2010): 187199. DOI: 10.20885 / millah.ed.khus.art11

Prastiawati, Fitriani dan Emile Satia Darma. "Peran Pembiayaan Baitul Maal Wat Tamwil terhadap Perkembangan Usaha dan Peningkatan Kesejahteraan Anggotanya dari Sektor Mikro Pedagang Pasar Tradisional”. Jurnal Akuntansi dan Investasi, 17, 2 (2016): 197-208. DOI: 10.18196/jai.2016.0055.197-208

Sanjaya, Sukma Ari. "Implementasi Undang-undang Nomor 1 Tahun 2013 tentang Lembaga Keuangan Mikro Terhadap Pembinaan dan Pengawasan Baitul Maal wat Tamwil oleh Otoritas Jasa Keuangan”. Skripsi, Fakultas Hukum Universitas Lampung, Bandar Lampung, 2019.

Siregar, Tania Theresia. "Pengawasan Otoritas Jasa Keuangan Terhadap Koperasi Simpan Pinjam Ilegal Terkait Investasi Ilegal 
dan Usaha Mikro Kecil Menengah (UMKM) Dalam Mencegah Praktek Pengumpulan Dana Masyarakat Secara Ilegal”. Skripsi, Fakultas Hukum Universitas Sumatera Utara, Medan, 2018.

\section{Peraturan Hukum}

Republik Indonesia. Undang-Undang Nomor 25 Tahun 1992 tentang Koperasi.

Republik Indonesia. Undang-Undang Nomor 8 Tahun 1999 tentang

Perlindungan Konsumen.

Republik Indonesia. Undang-Undang Nomor 28 Tahun 2004 tentang

Perubahan Atas Undang-Undang Nomor 16 Tahun 2001 tentang Yayasan.

Republik Indonesia. Undang-Undang Nomor 21 Tahun 2011 tentang

Otoritas Jasa Keuangan.

Republik Indonesia. Undang-undang Nomor 23 Tahun 2011 tentang

Pengelolaan Zakat.

Republik Indonesia. Undang-Undang Nomor 17 Tahun 2012 tentang

Perkoperasian

Republik Indonesia. Undang-Undang Nomor 1 Tahun 2013 tentang Lembaga Keuangan Mikro.

Republik Indonesia. Undang-Undang Nomor 17 Tahun 2013 tentang Organisasi Kemasyarakatan.

Republik Indonesia. Peraturan Pemerintah Nomor 58 Tahun 2001 tentang Pembinaan dan Pengawasan Penyelenggaraan Perlindungan Konsumen.

Republik Indonesia, Kementerian Negara Koperasi dan Usaha Kecil dan Menengah. Keputusan Menteri Nomor 91 / Kep/M.KUKM / IX/ 2004 tentang Petunjuk Pelaksanaan Kegiatan Usaha Koperasi Jasa Keuangan Syariah Menteri.

Republik Indonesia, Kementerian Negara Koperasi dan Usaha Kecil dan Menengah. Peraturan Menteri Nomor 39/Per/M.KUKM/ XII / 2007 tentang Pedoman Pengawasan Koperasi Jasa Keuangan Syariah dan Unit Jasa Keuangan Syariah Koperasi.

Republik Indonesia, Kementerian Negara Koperasi dan Usaha Kecil dan Menengah. Peraturan Menteri Nomor 35.2/Per/M.Kukm/ 
X/2007 tentang Standar Operasional Prosedur KJKS.

Republik Indonesia, Direktur Jenderal Pembangunan Daerah

Kementerian Dalam Negeri. Keputusan Nomor 538/PKKN/

IV/1997 tentang Status Badan Hukum untuk Lembaga

Keuangan Syariah.

Republik Indonesia, Otoritas Jasa Keuangan. Peraturan Nomor 01/

POJK.07/2013 tentang Perlindungan Konsumen Sektor Jasa

Keuangan.

Republik Indonesia, Otoritas Jasa Keuangan. Peraturan Nomor 14/

POJK.05/2014 tentang Pembinaan dan Pengawasan Lembaga

Keuangan Mikro.

Republik Indonesia, Otoritas Jasa Keuangan. Surat Edaran Nomor

1/SEOJK.07/ 2014 tentang Pelaksanaan Edukasi dalam Rangka meningkatkan Literasi Keuangan Kepada Konsumen dan/atau Masyarakat.

Republik Indonesia, Otoritas Jasa Keuangan. Surat Edaran Nomor 2 / SEOJK.07/ 2014 tentang Pelayanan dan Penyelesaian Pengaduan Konsumen pada Pelaku Usaha Jasa Keuangan. 